\title{
Phytochemical analysis and in vitro antioxidant activities of leaves, stems, flowers, and roots extracts of Bougainvillea spectabilis Willd.
}

\section{Vijender Singh', Vipul Aggrawal'}

${ }^{1}$ Department of Pharmacognosy and Phytochemistry, School of Pharmacy, Sharda University, Noida, Uttar Pradesh, India, ${ }^{2}$ Department of Pharmacognosy, School of Pharmacy, Monad University, Hapur, Uttar Pradesh, India

Abstract

Objective: Hydroalcoholic and alcoholic extracts of the various parts of Bougainvillea spectabilis Willd. (Nyctaginaceae) have been used as a natural therapeutic agent in traditional medicine to treat oxidative damage/ oxidative stress, and inflammation from ancient times. Materials and Methods: Research is principally focused on evaluating the effect of various parts of this plant on its anti-inflammatory and antioxidant effects. In vitro studies were conducted for anti-inflammatory and antioxidant activities. Results: Hydroalcoholic and alcoholic extracts of the various parts of the plants showed scavenging activity against 2, 2-diphenyl-1-picrylhydrazyl radical relative to Vitamin C (standard) at $P<0.05$, but an excellent activity was observed with flowers as compared with other parts of the plants in hydroalcoholic extract. A remarkable anti-inflammatory activity observed by hydroalcoholic extract $(10 \% \mathrm{w} / \mathrm{w})$ of flowers as compared to leaves, stem, and roots against diclofenac sodium (standard). The present investigation revealed that the hydroalcoholic extracts of the flowers of B. spectabilis Willd. exhibited significant antioxidant activity which is comparable to known standards.

Key words: Anti-inflammatory activities, antioxidant, Bougainvillea spectabilis Willd., estimations, screening of phytochemicals

\section{INTRODUCTION}

T The genus Bougainvillea is a native to South America and derived its name from Louis Antoine de Bougainville (1729-1811), an admiral in the French Navy who encountered the plant in Brazil, in 1768, and it was introduced to the rest of the world. ${ }^{[1]}$ The genus Bougainvillea in the Nyctaginaceae (4 O' clock) family of plants has 18 species, with three that are horticulturally important (in ornamental sense) Bougainvillea spectabilis, Bougainvillea glabra, and Bougainvillea peruviana $^{[2]}$ Bougainvillea species are not native to Montenegro, and they are primarily used as decorative plants in gardens.

Bougainvillea species have been shown to possess alkaloids, flavonoids, cardiac glycosides, saponines, ${ }^{[3]}$ and beta-cyanins.$^{[4]}$ Momordin IIc and two quercetin glycosides were isolated from $B$. spectabilis. In addition, n-octacos-9-enoic acid 8 was isolated from the roots of $B$. spectabilis.
The chemical constituents of the genus Bougainvillea have been extensively studied since $1970 .{ }^{[4,5]}$

Flowers - fresh flowers, bearing ivory-white bracts contain glycosides of quercetin and isorhamnetin. These glycosides are quercetin-xyloside and isorhamnetin-glucorhamnoside. ${ }^{[6-8]}$ Leaves - pinitol or D-chiro(+)-o-methyl inositol is a potent antidiabetic compound isolated from leaves, ${ }^{[9,10]}$ spinasterol, and quercetin. ${ }^{[11]}$ Fatty acids and fatty alcohols have been reported from roots and branches ${ }^{[12,13]}$. Eight peltogynoids, vogainvinone from $\mathrm{A}$ to $\mathrm{M}$ and flavonoids have also been reported from stem bark $^{[14,15]}$. Volatile compounds mainly methyl salicylate terpinolene, 2-furfural cadina-1, 4-diene, linalool etc ${ }^{[12]}$ have been reported in leaves and branches.

Address for correspondence:

Vijender Singh, School of Pharmacy, Sharda University, Noida, Uttar Pradesh, India. Phone: +91-9810347087.

E-mail: vijender.singh@sharda.ac.in

Received: 27-07-2018

Revised: $10-11-2018$

Accepted: 26-11-2018 
B. spectabilis leaves are reported to have medicinal properties such as antidiabetic, ${ }^{[3,16,17]}$ antiviral, ${ }^{[18]}$ antibacterial, ${ }^{[2,19]}$ antiinflammatory, ${ }^{[20]}$ larvicidal, ${ }^{[21]}$ and antifertility potential. ${ }^{[22]}$

Phytochemical investigation of all pats like leaves stems flowers and roots by hydroalcoholic and alcoholic extracts of B. spectabilis showed the presence of antioxidant and anti-inflammatory activities.

\section{MATERIALS AND METHODS}

\section{Collection of Plant Materials}

The whole plants of $B$. spectabilis Willd. were collected in February 2018 from the nearby area of Sharda University, Greater Noida, U. P.

\section{Authentication of Plant Material}

The plant material was authenticated as B. spectabilis Willd. by Ex. Chief Scientist, Department of Botany, Dr. H. B Singh and presently working in the Department of Herbology, AIMIL Pharmaceuticals (I) Ltd. A voucher specimen is preserved in the herbarium of School of Pharmacy, Sharda University, Greater Noida, U. P.

\section{Extraction of Plant Materials}

The plant material (each part) Bougainvillea $(1.0 \mathrm{~kg}$ ) was air dried, crushed to smaller pieces, redried, and coarsely powdered and was then exhaustively extracted with ethanol (95\%) and hydroalcoholic mixture (water:alcohol: 40:60) in a Soxhlet apparatus for $72 \mathrm{~h}$. The alcoholic and hydroalcoholic extracts were dried and dark brown masses were obtained.

\section{Preliminary Phytochemical Screening}

The alcoholic and hydroalcoholic extracts of each part of Bougainvillea were subjected to preliminary phytochemical investigation for the detection of the following metabolites: Alkaloids, carbohydrates, glycosides, phenolic compounds, flavonoids, protein and free amino acids, saponins, and sterols. ${ }^{[23]}$

\section{Quantitative Estimation of Phytoconstituents}

\section{Quantification of alkaloids}

The content of alkaloid in the plant sample was determined. ${ }^{[23]}$ $5 \mathrm{~g}$ of the sample was weighed and transferred in a beaker and $200 \mathrm{ml}$ of $10 \%$ acidic acid in ethanol was added. The mixture was covered and allowed to stand for $4 \mathrm{~h}$ at ambient temperature. The filtered extract was concentrated on a water bath to $14^{\text {th }}$ of the original volume. Concentrated $\mathrm{NH}_{4} \mathrm{OH}$ was added dropwise to the extract until the precipitation was complete. The whole solution was allowed to settle and the precipitate was collected and washed with dilute $\mathrm{NH}_{4} \mathrm{OH}$ and then filtered. The residue obtained was dried and weighed.

\section{Quantification estimation of saponins}

The saponin content in the different parts of the plant was determined using the dried hydroalcoholic and alcoholic. ${ }^{[24]}$ The leaves, stems, flowers, and roots were ground and $20 \mathrm{~g}$ of it were transferred into a conical flask and $100 \mathrm{ml}$ of $20 \%$ aqueous ethanol was added. The sample was heated over a hot water bath for $4 \mathrm{~h}$ with continuous stirring at about $55^{\circ} \mathrm{C}$. The mixture was filtered and the residue was reextracted with another $200 \mathrm{ml}$ of $20 \%$ ethanol. The combined extracts were reduced to $40 \mathrm{ml}$ over a water bath at $90^{\circ} \mathrm{C}$. The concentrate was transferred into a $250 \mathrm{ml}$ separating funnel and $20 \mathrm{ml}$ diethyl was added and shaken vigorously. The aqueous layer was recovered while the ether layer was discarded. The purification process was repeated. $60 \mathrm{ml}$ of n-butanol was added and the combines of $n$ - butanol extracts were washed twice with $10 \mathrm{ml}$ of $5 \%$ aqueous $\mathrm{NaCl}$. The remaining solution was evaporated on a water bath. After evaporation, the samples were dried in the oven to obtain a constant weight. The saponin content was calculated as percentage.

\section{Quantification of total phenolic contents}

Using modified Folin-Ciocalteu method, ${ }^{[25]}$ total phenol contents in the extracts were determined.

About $50 \mathrm{lL}$ aliquots of $12.5,25,50,100,200$, and $400 \mathrm{Lg} / \mathrm{ml}$ methanolic gallic acid solutions were mixed with $100 \mathrm{lL}$ Folin-Ciocalteu reagent (diluted 10-fold) and 100 1L (75 g/L) sodium carbonate.

The mixture was incubated at $25^{\circ} \mathrm{C}$ for $30 \mathrm{~min}$, the quantitative phenolic estimation was performed at $765 \mathrm{~nm}$. The calibration curve was constructed by plotting the absorbance against concentration. A similar procedure was adopted for the test samples as described above. Total phenolic content was expressed as milligrams of gallic acid equivalent (GAE) per $g$ of extract using the following equation based on the calibration curve: $y=0.0003 x+0.0716, R 2=0.9365$, where $\mathrm{x}$ was the absorbance and $\mathrm{y}$ was the tannic acid equivalent (mg/g).

\section{Quantification of Flavonoids}

Estimation of the total flavonoids in the plant extracts was carried out using the method. ${ }^{[26]} 0.5 \mathrm{ml}$ of $2 \% \mathrm{AlCl}_{3}$ ethanol solution was added to $0.5 \mathrm{ml}$ of sample. After $1 \mathrm{~h}$ at room temperature, the absorbance was measured at $420 \mathrm{~nm}$. Extract samples were evaluated at a final concentration of $1 \mathrm{mg} / \mathrm{ml}$. Total flavonoid content was calculated as quercetin $(\mathrm{mg} / \mathrm{g})$ using the following equation based on the calibration curve: $y=0.0255 x, R 2=0.9812$, where $x$ was the absorbance and $y$ was the quercetin equivalent $(\mathrm{mg} / \mathrm{g})$. 


\section{In vitro evaluation of $B$. spectabilis}

\section{Determination of antioxidant activity}

\section{2,2-diphenyl-1-picrylhydrazyl (DPPH) radical scavenging activity}

Preparation of extracts

The air-dried and coarsely powdered material (1000 g) was exhaustively extracted with hydroalcoholic mixture and alcohol in a reflux condenser for $4-5 \mathrm{~h}$. The extracts obtained were dried under reduced pressure to obtain a brownishcolored residue.

Preparation of Stock solution of DPPH

About $3.94 \mathrm{~g}$ of DPPH was dissolved in $1000 \mathrm{ml}$ of methanol to prepare $10 \mathrm{mM}$ solution. Transferred $1 \mathrm{ml}$ of this solution to a $100 \mathrm{ml}$ volumetric flask and diluted it up to $100 \mathrm{ml}$ with methanol to make a concentration of $0.1 \mathrm{mM}$. The solution was kept in darkness for $30 \mathrm{~min}$ to complete the reaction.

About $1 \mathrm{ml}$ of DPPH solution was added to $1 \mathrm{ml}$ of different extracts and allowed to stand at room temperature for $30 \mathrm{~min}$, and then, absorbance was measured at $517 \mathrm{~nm}$ in a spectrophotometer. Similarly, $1 \mathrm{ml}$ extracts in distilled water were added to $0.6 \mathrm{ml}$ of hydrogen peroxide solution and the absorbance was measured at $230 \mathrm{~nm}$ in a spectrophotometer. The percentage inhibition was measured by the following formula: ${ }^{[27]}$

$\%$ inhibition $=(\mathrm{Ac}-\mathrm{At}) \times 100 / \mathrm{Ac}$

Where, Ac is the absorbance of control and At is the absorbance of test sample.

\section{Anti-inflammatory activity}

The reaction mixture $(5 \mathrm{ml})$ consisted of $0.2 \mathrm{ml}$ of egg albumin (from fresh hen's egg), $2.8 \mathrm{ml}$ of phosphate-buffered saline, $\mathrm{pH} \mathrm{6.4}$, and $2 \mathrm{ml}$ of varying concentrations of alcoholic extract of clove oil so that final concentrations becomes 100, 200, 400, 800 , and $1000 \mu \mathrm{g} / \mathrm{ml}$. Similar volume of double-distilled water served as control. Then, the mixtures were incubated at $37 \pm$ $2^{\circ} \mathrm{C}$ in biochemical oxygen demand incubator for $15 \mathrm{~min}$ and then heated at $70^{\circ} \mathrm{C}$ for $5 \mathrm{~min}$. After cooling, their absorbance was measured at $660 \mathrm{~nm}$. Diclofenac sodium $(100 \mu \mathrm{g} / \mathrm{ml})$ was used as reference drug. The percentage inhibition of protein denaturation was calculated using the following formula: ${ }^{[2]}$

Percentage inhibition $=($ Abs control - Abs test sample $) \times 100 /$ Abs control,

Where, Abs - Absorbance.

\section{RESULTS AND DISCUSSION}

\section{Qualitative Phytochemical Screening}

Alkaloids, cardiac glycosides, flavonoids, saponins, terpenoids, and tannins have given the positive test in the different parts of the plant and summarized in Table 1.

\section{Quantitative Estimation of Phytoconstituents}

\section{Alkaloids}

The maximum amount of alkaloids has been reported in plant roots and followed by leaves, stems, and flowers in both the extracts. Results have been summarized in Tables 2 and 3.

\begin{tabular}{|c|c|c|c|c|c|c|c|c|c|c|c|c|c|}
\hline \multirow[t]{3}{*}{ Phytoconstituents } & \multirow[t]{3}{*}{ Test } & \multicolumn{12}{|c|}{ Qualitative test of different parts with different extracts } \\
\hline & & \multicolumn{3}{|c|}{ Leaves } & \multicolumn{3}{|c|}{ Stems } & \multicolumn{3}{|c|}{ Flowers } & \multicolumn{3}{|c|}{ Roots } \\
\hline & & $\mathbf{P}$ & C & A & $\mathbf{P}$ & C & A & $\mathbf{P}$ & C & A & $\mathbf{P}$ & C & A \\
\hline Alkaloid & Wagner & - & + & + & - & + & - & - & - & - & - & + & - \\
\hline Cardiac glycosides & Keller-Killiani & - & + & + & & & & & & & & & \\
\hline Flavonoids & Alkaline & - & + & + & - & + & + & + & + & + & - & - & - \\
\hline Phenols & Ferric chloride & - & - & - & - & - & - & - & - & - & - & - & - \\
\hline Saponins & Foam & - & + & + & - & + & + & - & + & + & - & + & + \\
\hline Terpenoids & Salkowski & + & + & - & + & + & - & + & + & - & + & + & - \\
\hline Quinones & - & - & - & - & & & & & & & & & \\
\hline Tannins & Braymer & - & - & + & - & - & + & - & - & + & - & - & + \\
\hline Sterols & Liebermann- Burchard & - & - & - & - & - & - & - & - & - & - & - & - \\
\hline $\begin{array}{l}\text { Amino acids and } \\
\text { proteins }\end{array}$ & Ninhydrin & - & - & - & - & - & - & - & - & - & - & - & - \\
\hline Oxalates & - & - & - & - & - & - & - & - & - & - & - & - & - \\
\hline
\end{tabular}

P: Petroleum ether, C: Chloroform, A: Alcohol, where “+” indicates positive and “-“ indicates negative 


\begin{tabular}{l}
$\begin{array}{l}\text { Singh and Aggrawal: Phytochemical analysis and in-vitro antioxidant activities of leaves, stems, flowers and roots extracts of } \\
\text { Bougainvillea spectabilis Willd }\end{array}$ \\
$\begin{array}{l}\text { Table 2: Phytochemical constituents of Bougainvillea spectabilis Willd. from different parts in alcoholic extracts } \\
\text { Phytoconstituents estimated }\end{array}$ \\
\cline { 2 - 5 }
\end{tabular}

GAE: Gallic acid equivalents

Table 3: Phytochemical constituents of Bougainvillea spectabilis Willd. from different parts in hydroalcoholic extracts

Phytoconstituents

\begin{tabular}{|c|c|c|c|c|}
\hline & \\
\hline & Leaves & Stems & Flowers & Roots \\
\hline Total phenolic contents (g of GAE) & 0.39 & 0.20 & 0.15 & 0.07 \\
\hline Total flavonoids ( $\mathrm{g}$ of quercetin equivalents) & 5.1 & 2.07 & 5.28 & 0.4 \\
\hline Alkaloids & 26.0 & 09.2 & 1.68 & 28.0 \\
\hline Saponins & 8.8 & 3.8 & 0.9 & 10.4 \\
\hline
\end{tabular}

\section{Table 4: Antioxidant activity of dried hydroalcoholic extracts obtained from different parts of Bougainvillea}

\section{spectabilis Willd.}

\begin{tabular}{lccccc} 
Concentration $(\mu \mathrm{g} / \mathrm{ml})$ & Roots & Flowers & Stems & Leaves & Vitamin C \\
\hline 10 & $31.20 \pm 2.91$ & $39.22 \pm 3.65$ & $32.32 \pm 3.24$ & $36.76 \pm 2.10$ & $46.35 \pm 3.31$ \\
50 & $33.85 \pm 2.62$ & $59.99 \pm 2.63$ & $33.67 \pm 2.67$ & $46.98 \pm 3.23$ & $71.66 \pm 6.11$ \\
100 & $35.76 \pm 2.37$ & $60.21 \pm 3.43$ & $47.89 \pm 1.98$ & $57.89 \pm 2.98$ & $79.10 \pm 5.80$ \\
150 & $37.90 \pm 2.43$ & $71.28 \pm 2.52$ & $57.98 \pm 2.67$ & $68.96 \pm 3.87$ & $87.44 \pm 4.74$ \\
200 & $38.28 \pm 3.13$ & $89.98 \pm 3.21$ & $62.86 \pm 2.54$ & $79.18 \pm 2.76$ & $94.44 \pm 4.13$ \\
EC50 & $39.28 \pm 3.12$ & $82.36 \pm 2.76$ & $58.61 \pm 2.71$ & $69.76 \pm 3.34$ & $14.90 \pm 3.13$ \\
\hline
\end{tabular}

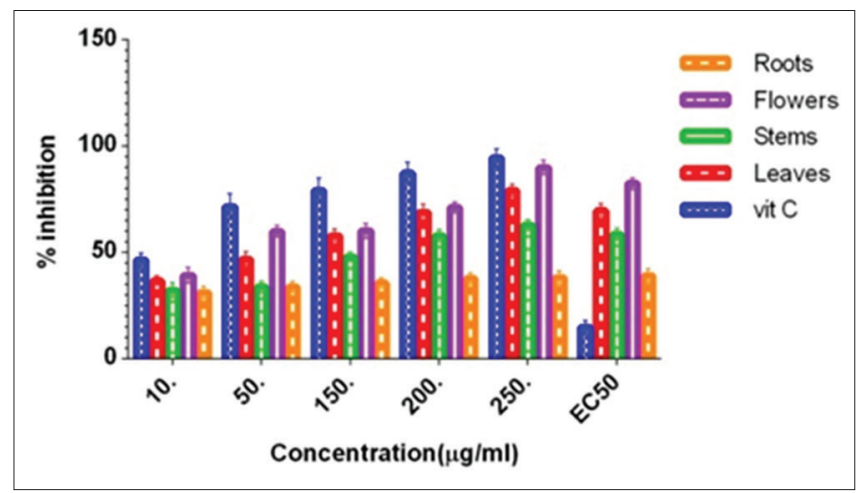

Figure 1: Antioxidant activity (bar diagram) of dried hydroalcoholic extracts obtained from different parts of Bougainvillea spectabilis

\section{Saponins}

The maximum amount of saponins has been reported in plant roots and followed by leaves, stems, and flowers in both the extracts. Results have been summarized in Tables 2 and 3.

\section{Total phenolic contents ( $g$ of GAE)}

The maximum amount of phenolic contents ( $g$ of GAE) has been reported in plant leaves and followed by stems, flowers,

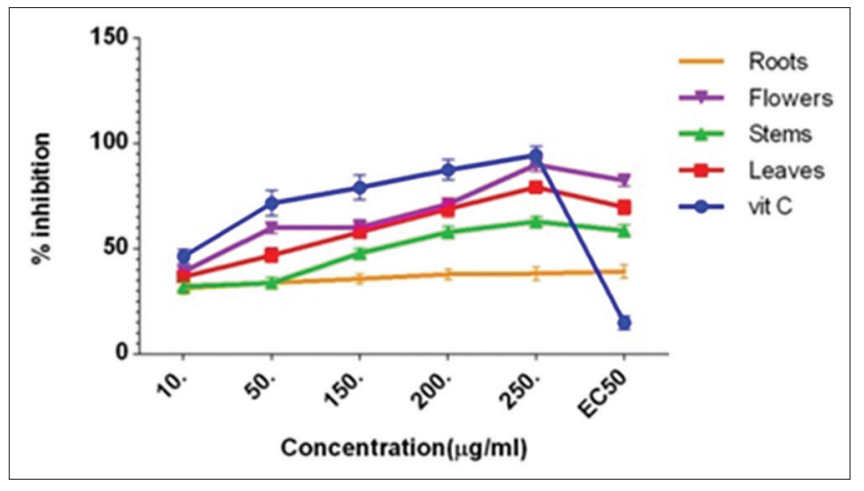

Figure 2: Antioxidant activity of dried hydroalcoholic extracts obtained from different parts of Bougainvillea spectabilis

and roots in both the extracts. Results have been summarized in Tables 2 and 3.

\section{Total flavonoids (g of quercetin equivalents)}

The maximum amount of total flavonoids ( $\mathrm{g}$ of quercetin equivalents) has been reported in plant flowers and followed by leaves, stems, and roots in both the extracts. Results have been summarized in Tables 2 and 3 . 


Table 5: Antioxidant activity of dried alcoholic extracts obtained from different parts of Bougainvillea spectabilis
Willd.
\begin{tabular}{lccccc} 
Concentration $(\boldsymbol{\mu g} / \mathbf{m l})$ & Roots & Flowers & Stems & Leaves & Vitamin C \\
\hline 10 & $25.97 \pm 2.43$ & $38.54 \pm 2.56$ & $34.89 \pm 2.14$ & $29.98 \pm 1.52$ & $46.35 \pm 3.31$ \\
50 & $27.99 \pm 2.52$ & $38.78 \pm 2.54$ & $34.54 \pm 3.17$ & $29.99 \pm 0.78$ & $71.66 \pm 6.11$ \\
100 & $28.89 \pm 3.37$ & $39.98 \pm 2.29$ & $35.56 \pm 2.28$ & $30.79 \pm 0.91$ & $79.10 \pm 5.80$ \\
150 & $29.45 \pm 2.29$ & $42.76 \pm 3.43$ & $36.56 \pm 3.94$ & $31.28 \pm 0.43$ & $87.44 \pm 4.74$ \\
200 & $30.48 \pm 2.49$ & $43.57 \pm 2.58$ & $39.89 \pm 2.65$ & $32.98 \pm 0.37$ & $94.44 \pm 4.13$ \\
EC50 & $30.21 \pm 3.28$ & $43.45 \pm 2.54$ & $39.56 \pm 2.29$ & $32.34 \pm 0.46$ & $14.90 \pm 3.13$ \\
\hline
\end{tabular}

\begin{tabular}{lccccc}
\multicolumn{5}{l}{ Table 6: Anti-inflammatory activity of dried hydroalcoholic extracts obtained from different parts of Bougainvillea } \\
spectabilis Willd.
\end{tabular}

\begin{tabular}{|c|c|c|c|c|c|}
\hline Concentration $(\mu \mathrm{g} / \mathrm{ml})$ & Roots & Flowers & Stems & Leaves & Diclofenac sod. \\
\hline 100 & $11.97 \pm 3.32$ & $26.67 \pm 2.32$ & $14.74 \pm 3.10$ & $15.86 \pm 3.31$ & $40.24 \pm 1.32$ \\
\hline 200 & $17.38 \pm 2.67$ & $29.96 \pm 3.12$ & $17.77 \pm 1.23$ & $18.22 \pm 6.11$ & $46.24 \pm 2.78$ \\
\hline 300 & $20.71 \pm 2.98$ & $39.19 \pm 2.32$ & $19.68 \pm 1.98$ & $21.31 \pm 5.80$ & $54.24 \pm 2.91$ \\
\hline 400 & $22.12 \pm 2.67$ & $42.27 \pm 3.52$ & $23.19 \pm 2.87$ & $28.22 \pm 4.74$ & $65.24 \pm 2.43$ \\
\hline 500 & $24.76 \pm 2.59$ & $44.28 \pm 2.56$ & $25.34 \pm 2.76$ & $36.67 \pm 4.13$ & $72.24 \pm 3.37$ \\
\hline
\end{tabular}

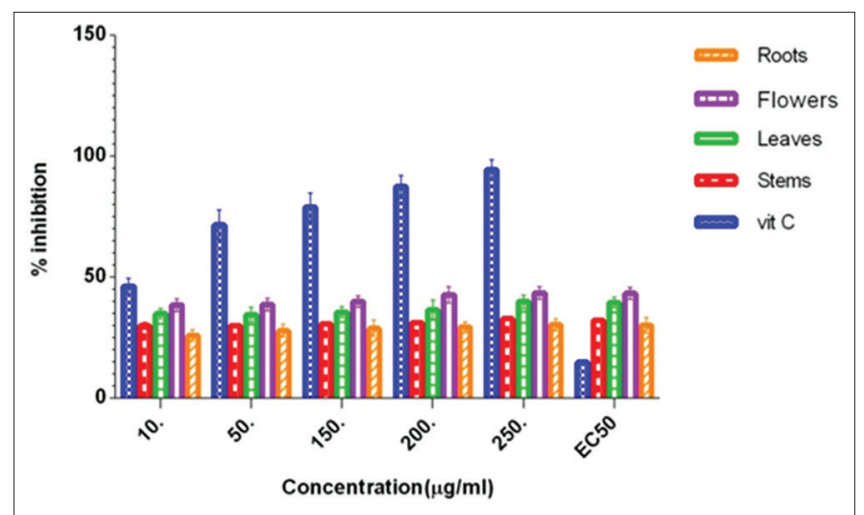

Figure 3: Antioxidant activity (bar diagram) of dried alcoholic extracts obtained from different parts of Bougainvillea spectabilis

\section{In vitro activities}

\section{Antioxidant activity}

The results were summarized in Tables 4 and 5 and Figures 1-4. It was observed that the scavenging activity of

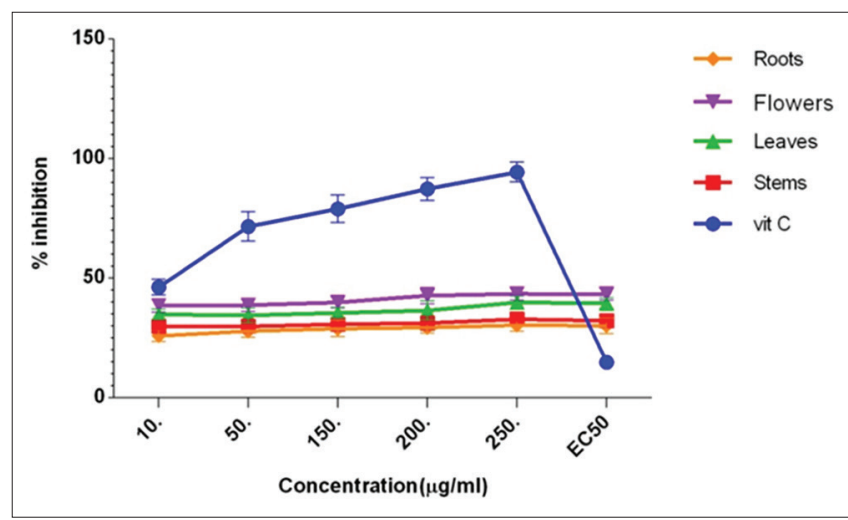

Figure 4: Antioxidant activity of dried alcoholic extracts obtained from different parts of Bougainvillea spectabilis

dried hydroalcoholic and alcoholic extracts of plant in all concentrations from 10 to $250 \mu \mathrm{g} / \mathrm{ml}$ was dose dependent. The results demonstrated that the alcoholic extract at concentration of $10 \% \mathrm{w} / \mathrm{w}$ showed maximum scavenging activity and showed maximum inhibition of reactive oxygen species with EC value of $15 \mathrm{ug} / \mathrm{ml}$. 


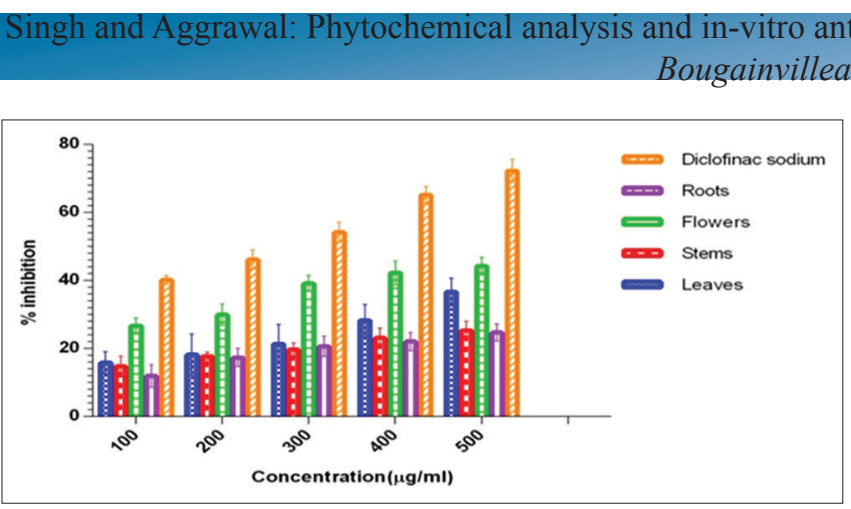

Figure 5: Anti-inflammatory activity (bar diagram) of dried alcoholic extracts obtained from different parts of Bougainvillea spectabilis

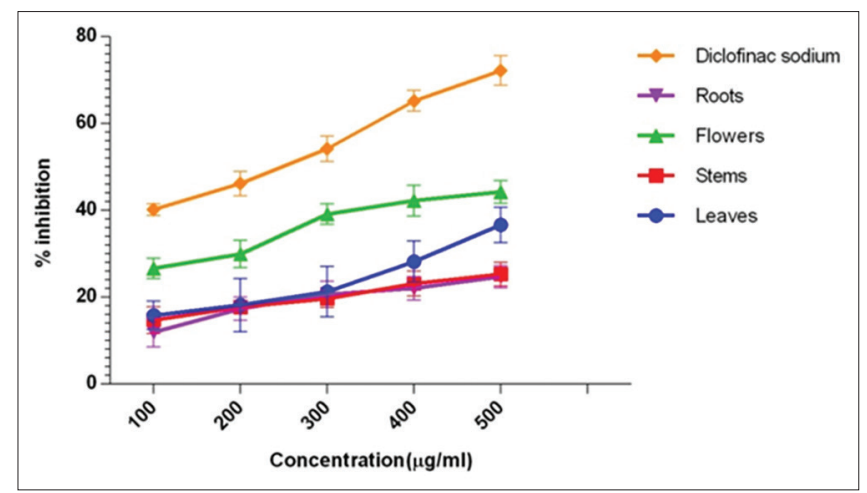

Figure 6: Anti-inflammatory activity of dried alcoholic extracts obtained from different parts of Bougainvillea spectabilis

\section{Anti-inflammatory Activity}

The results were summarized in Tables 6 and 7 and Figures 5-8. Dose-dependent anti-inflammatory response was obtained with dried hydroalcoholic and alcoholic extracts and 10\% w/w alcoholic extract showed significantly higher percentage of inhibition comparable results to that of diclofenac sodium taken as reference standard. Denaturation of tissue proteins is one of the well-documented causes of inflammation.

\section{CONCLUSION}

Plants are the valuable source of therapeutic agents in the armory of modern medicine itself. Natural products that have come into modern therapy are the result of an approach that has been adopted during the past 50 years.

Medicinal herbs have been of use for thousands of years in one form or another under the indigenous systems of medicine such as Ayurveda, Siddha, and Unani.

The present study provides scientific evidence for antioxidative, free radical scavenging, and anti-inflammatory activities from all parts of Bougainvillea in in vitro models that are due to various bioactive compounds.

Further studies are required to isolate and identify the compounds that are responsible for the various therapeutic

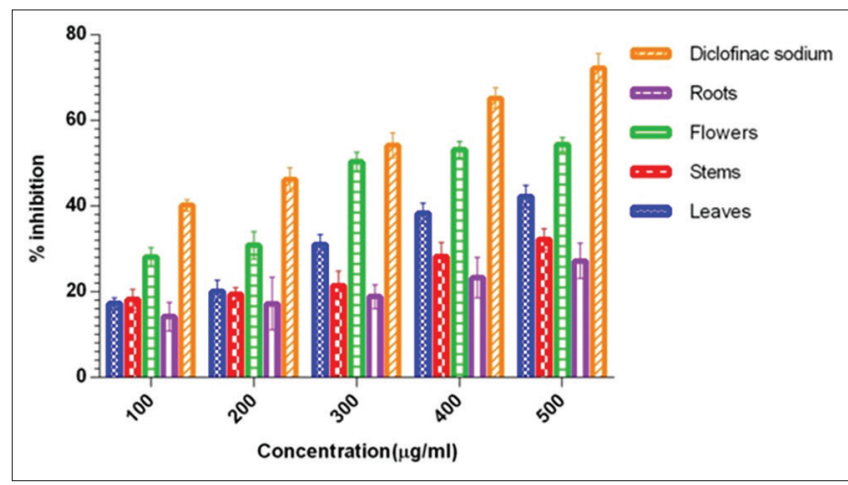

Figure 7: Anti-inflammatory activity (bar diagram) of dried hydroalcoholic extracts obtained from different parts of Bougainvillea spectabilis

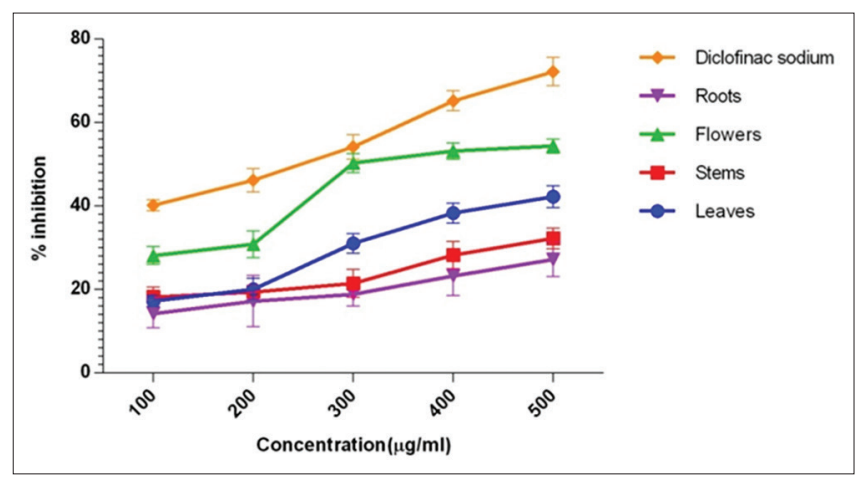

Figure 8: Anti-inflammatory activity of dried hydroalcoholic extracts obtained from different parts of Bougainvillea spectabilis

activities with proper scientific evaluation and support so that it can be efficiently incorporated into drugs.

\section{ACKNOWLEDGMENT}

The authors are thankful to Dr. Robin Kumar, Senior Scientific Officer, Indian Pharmacopoeia Commission, Ghaziabad, U.P., India, to provide help in completion of this research work.

\section{REFERENCES}

1. Struwig M, Siebert S. An introduction to the four-o' clocks of southern Africa. Plant Life 2010;39:66-70.

2. Gupta V, George M, Joseph L, Singhal M, Singh HP. Evaluation of anti-bacterial activity of Bougainvillea glabra 'snow white' and Bougainvillea glabra 'choicy'. J Chem Pharm Res 2009;1:233-7.

3. Adebayo GI, Alabi OT, Owoyele BV, Soladoye AO. Anti-diabetic properties of the aqueous leaf extract of Bougainvillea glabra (glory of the garden) on alloxaninduced diabetic rats. Rec Nat Prod 2009;3:187-92.

4. Piattelli M, Imperato E. Betacyanins from Bougainvillea. Phytochemistry 1970;9:455-8. 
5. Piattelli M, Imperato F. Pigments of Bougainvillea glabra. Phytochemistry 1970;9:2557-60.

6. Rastogi RP, Mehrotra BN. Compendium of Indian Medicinal Plants. Vol. 3. Lucknow: CDRI; 1993. p. 2.

7. Rastogi RP. Mehrotra BN. Compendium of Indian Medicinal Plants. Vol. 4. Lucknow: CDRI; 1995. p. 115.

8. Pullaiah T. Encyclopedia of World Medicinal Plants. Vol. 1. New Delhi: Regency Publications; 2006. p. 346.

9. Narayanan CR, Joshi DD, Mujumdar AM, Dheme VV. Pinitol - A new antidiabetic compound from the leaves of Bougainvellea spectabilis. Curr Sci 1987;56:139-41.

10. Council of Scientific and Industrial Research. The Wealth of India, Raw Materials. New Delhi: Council of Scientific and Industrial Research; 1999. p. 148.

11. Chang WS, Lee YJ, Lu FJ, Chaing HC. Inhibitory effects of flovoinds on xanthine oxidase. Anticancer Res 1993;13:2165-70.

12. Vukovic N, Kacaniova M, Hleba L, Sukdolak S. Chemical composition of the essential oil of Bougainvillea spectabilis from montenegro. J Essent Oil Bear Plants 2013;16:212-5.

13. Singh S, Reddu SK, Sharma SK, Ali M. New unsaturated fatty acid from roots of Bougainvillea spectabilis Willd. Asian J Chem 2008;21:4744-8.

14. Do LT, Aree T, Siripong P, Pham TN, Nguyen PK, TipPyang S, et al. Bougainvinones A-H, peltogynoids from the stem bark of purple Bougainvillea spectabilis and their cytotoxic activity. J Nat Prod 2016;79:939-45.

15. Do LT, Aree T, Siripong P, Vo NT, Nguyen TT, Nguyen PK, et al. Cytotoxic flavones from the stem bark of Bougainvillea spectabilis willd. Planta Med 2018;84:129-34.

16. Amal HA. Biologically active saponins from Bougainvillea spectabilis growing in Egypt. Asian J Chem 2009;7:5510-6.

17. Sumitra S, Sanjay KR, Surendra KS, Mohammad A. New unsaturated fatty acid from roots of Bougainvillea spectabilis willd. Asian J Chem 2009;6:4744-8.
18. Bolognesi A, Polito L, Olivieri F, Valbonesi P, Barbieri $\mathrm{L}$, Battelli $\mathrm{MG}$, et al. New ribosome-inactivating proteins with polynucleotide: Adenosine glycosidase and antiviral activities from Basella rubra L. And Bougainvillea spectabilis willd. Planta 1997;203:422-9.

19. Umamaheswari A, Shreevidya R, Nuni A. In vitro antibacterial activity of Bougainvillea spectabilis leaves extracts. Adv Biol Res 2008;2:1-5.

20. Joshi DD, Mujumdar AM, Narayanan CR. Antiinflammatory activity of Bougainvillea spectabilis leaves. Indian J Pharm Sci 1984;46:187-8.

21. Ali MS, Ibrahim SA, Ahmed F, Pervez MK. Color versus bioactivity in the flowers of Bougainvillea spectabilis (Nyctaginaceae). Nat Prod Res 2005;19:1-5.

22. Mishra N, Joshi S, Tandon VL, Munjal A. Evaluation of antifertility potential of aqueous extract of Bougainvillea spectabilis leaves in Swiss albino mice. Int J Pharm Sci Drug Res 2009;1:19-23.

23. Harborne JB. Phytochemical Methods. London: Chapman and Hall Ltd.; 1973. p. 49-188.

24. Obadoni BO, Ochuko PO. Phytochemical studies and comparative efficacy of the crude extract of some homeostatic plants in Edo and Delta states of Nigeria. Glob J Pure Apl Sci 2001;2001:203-8.

25. Kaur C, Kapoor HC. Antioxidant activity and total phenolic content of some Asian vegetables. Int J Food Sci Technol 2002;37:153-61.

26. Ordonez AA, Gomez JD, Vattuone MA, Isla MI. Antioxidant activities of Sechium edule (Jacq.) Swart extracts. Food Chem 2006;97:452-8.

27. Mahalwal VS, Gunjan DG. Volatile constituents and biological activities of dried unripe flower buds of Syzygium aromaticum Linn. Syn. Eugenia caryophyllus (Spreng). Int J Glob Pharm 2017;11:8-14.

Source of Support: Nil. Conflict of Interest: None declared. 